\title{
Description of two new species of Naatlo (Araneae: Theridiosomatidae) from Brazil
}

\author{
Everton N. L. Rodrigues ${ }^{1} \&$ Arno A. Lise ${ }^{2}$
}

\begin{abstract}
${ }^{1}$ Museu de Ciências Naturais, Fundação Zoobotânica do Rio Grande do Sul. Rua Doutor Salvador França 1427, 90690-000 Porto Alegre, Rio Grande do Sul, Brasil. E-mail: enlrodrigues@yahoo.com.br

2 Laboratório de Aracnologia, Pontifícia Universidade Católica do Rio Grande do Sul. Avenida Ipiranga 6681, prédio 12C, sala 244, 90619-900 Porto Alegre, Rio Grande do Sul, Brasil. E-mail: lisearno@pucrs.br
\end{abstract}

\begin{abstract}
Naatlo Coddington, 1986 is diagnosed by the presence of the epigynal flap in the females and the reduced conductor and the more complex embolic tip in the males. In this paper it are described and illustrated two news species from Brazil: N. serrana sp. nov. from state of Rio Grande do Sul and N. maturaca sp. nov. from states of Amazonas, Pará and Mato Grosso.

KEY WORDS. Epeirotypinae; Neotropical region; spiders; taxonomy.
\end{abstract}

RESUMO. Descrição de duas espécies novas de Naatlo (Araneae: Theridiosomatidae) do Brasil. Naatlo Coddington, 1986 é diagnosticado pela presença de uma aba no epígino das fêmeas e o condutor reduzido e ápice do embolo mais complexo nos machos. Neste trabalho duas espécies novas do Brasil são descritas e ilustradas: N. serrana sp. nov. do Rio Grande do Sul e N. maturaca sp. nov. do Amazonas, Pará e Mato Grosso.

PALAVRAS-CHAVE. Aranhas; Epeirotypinae; região Neotropical; taxonomia.

Epeirotypinae Archer, 1953 includes the genera Epeirotypus O. Pickard-Cambridge, 1894 and Naatlo Coddington, 1986. According to CODDINGTON (1986) the subfamily is diagnosed by the rounded median apophysis that has a shape of notched disk, in both genera, unique among theridiosomatids, by the flat paracymbium also on both genera, by the blade-like median apophysis, broadly attached to cymbium; the tegula are much expanded on their lateral faces and the epigynum, in both genera, is a convex bulging dome, whose posterior margins is closely to the abdominal ventral wall.

Naatlo is diagnosed by the presence of the epigynal flap hinged anteriorly and covering the copulatory bursa in the females and the reduced conductor and the more complex embolic tip in the males (CODDINGTON 1986). Naatlo includes four Neotropical species (Platnick 2007), from these, two occur in Brazil, $N$. fauna (Simon, 1897), recorded from material of the state of Rio de Janeiro and N. splendida (Taczanowski, 1879) from the state of Amapá. Rodrigues \& OTT (2005) reported N. splendida also for the states of Amazonas, Pará and Rio Grande do Sul. The knowledge about Naatlo in Brazil is precarious, and the Brazilian fauna needs to be more studied. In this paper two new species are described. One from the state of Rio Grande do Sul and another none from the states of Amazonas, Pará and Mato Grosso.

The specimens examined were deposited in the collection of Araneae of "Museu de Ciências Naturais, Fundação Zoobotânica do Rio Grande do Sul (MCN, E.H. Buckup)" and
"Museu de Ciências e Tecnologia da Pontifícia Universidade Católica do Rio Grande do Sul, (MCTP, A.A. Lise)", both from Porto Alegre. The description style and terminology of palpal morphology follow CoDDINGTON $(1986,1990)$. The epigynum of females was clarified with lactic acid for approximately $30 \mathrm{~min}$ utes, since the internal structures could be perfectly visualized. Measurements are expressed in millimeters. Abbreviations: (AME) anterior median eyes, (ALE) anterior lateral eyes, (PLE) posterior lateral eyes, (PME) posterior median eyes and MOQ median ocular quadrangle. The scanning electron micrographs (SEM) were made using a Philips XL 20 electronic microscope of the Centro de Microscopia e Microanálises of Pontifícia Universidade Católica do Rio Grande do Sul (PUCRS).

\section{Naatlo serrana sp. nov.}

Figs $1-27$

Types. Male holotype from BraziL, Rio Grande do Sul: São Francisco de Paula (Centro de Pesquisas e Conservação da Natureza Pró-Mata), 05-09.III.1997, A.A. Lise leg. (MCTP 14079). Paratypes: 5 males and 5 females, with same locality as holotype, 21-24.III.1995-20.III.1998, all collected by A.A. Lise leg. (MCTP 37598, 37599, 37600, 37618); 5 males and 5 females, same locality and collector as holotype, 23.I.1981 (MCN 9535).

Etymology. The specific name is an adjective that means the one who lives on the height lands called "serra" in the state of Rio Grande do Sul.

Revista Brasileira de Zoologia 25 (2): 299-308, June, 2008 

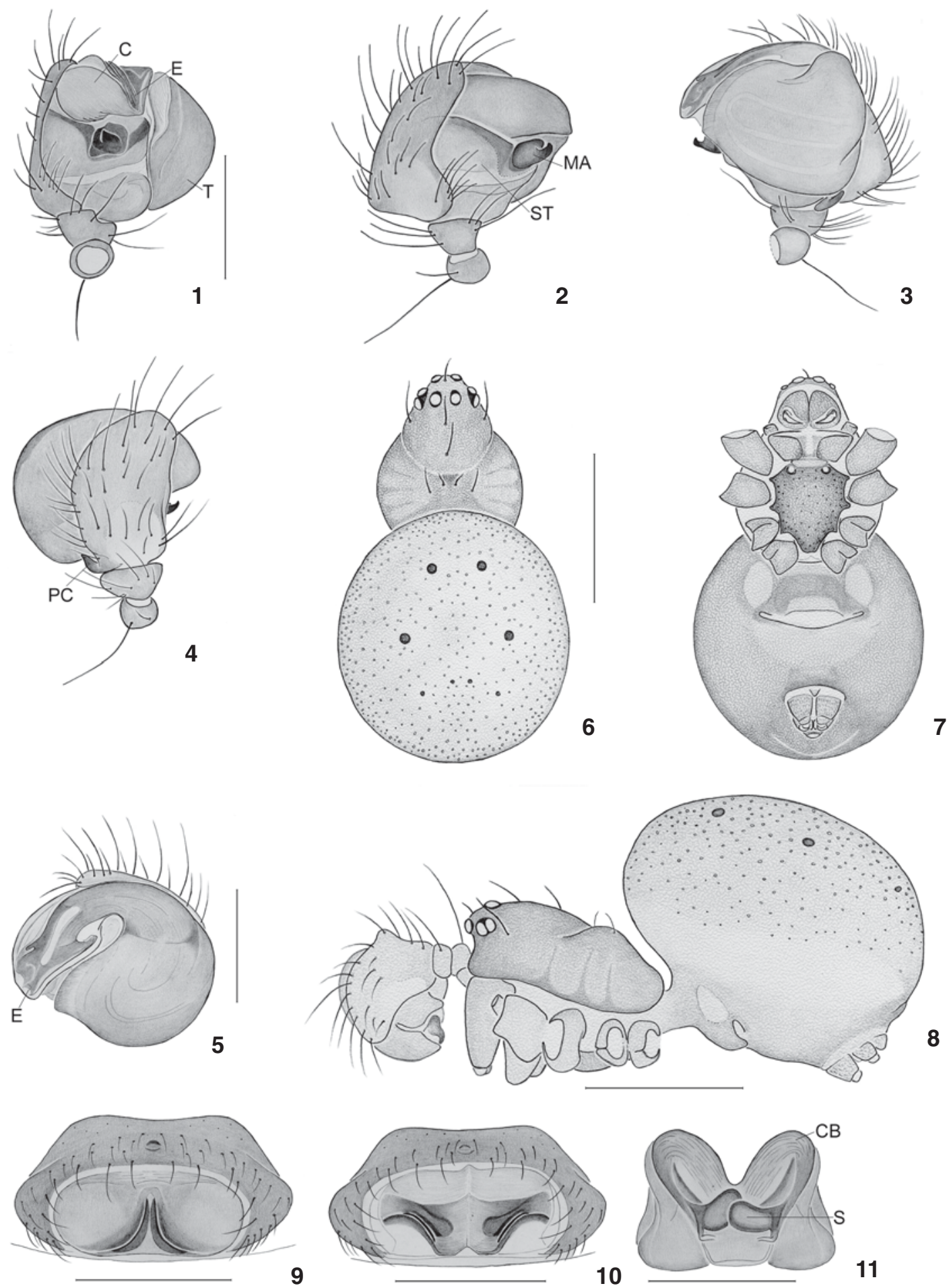

Figures 1-11. Naatlo serrana sp. nov.: (1-5) male palp: (1) ventral view, (2) ectal view, (3) mesal view, (4) dorsal view, (5) apical view; (68) male body: (6) dorsal view, (7) ventral view, (8) lateral view; (9-11) female epygine: (9) ventral view; (10) ventral view, flap removed; (11) dorsal view, cleared.(C) conductor; (CB) copulatory bursae; (E) embolus; (MA) median apophysis; (S) spermathecae, (ST) subtegulum, (T) tegulum, $(P)$ paracymbium. Scale lines: (1-5 and 9-11) 0,5 mm, (6-8) $1 \mathrm{~mm}$.

Revista Brasileira de Zoologia 25 (2): 299-308, June, 2008 

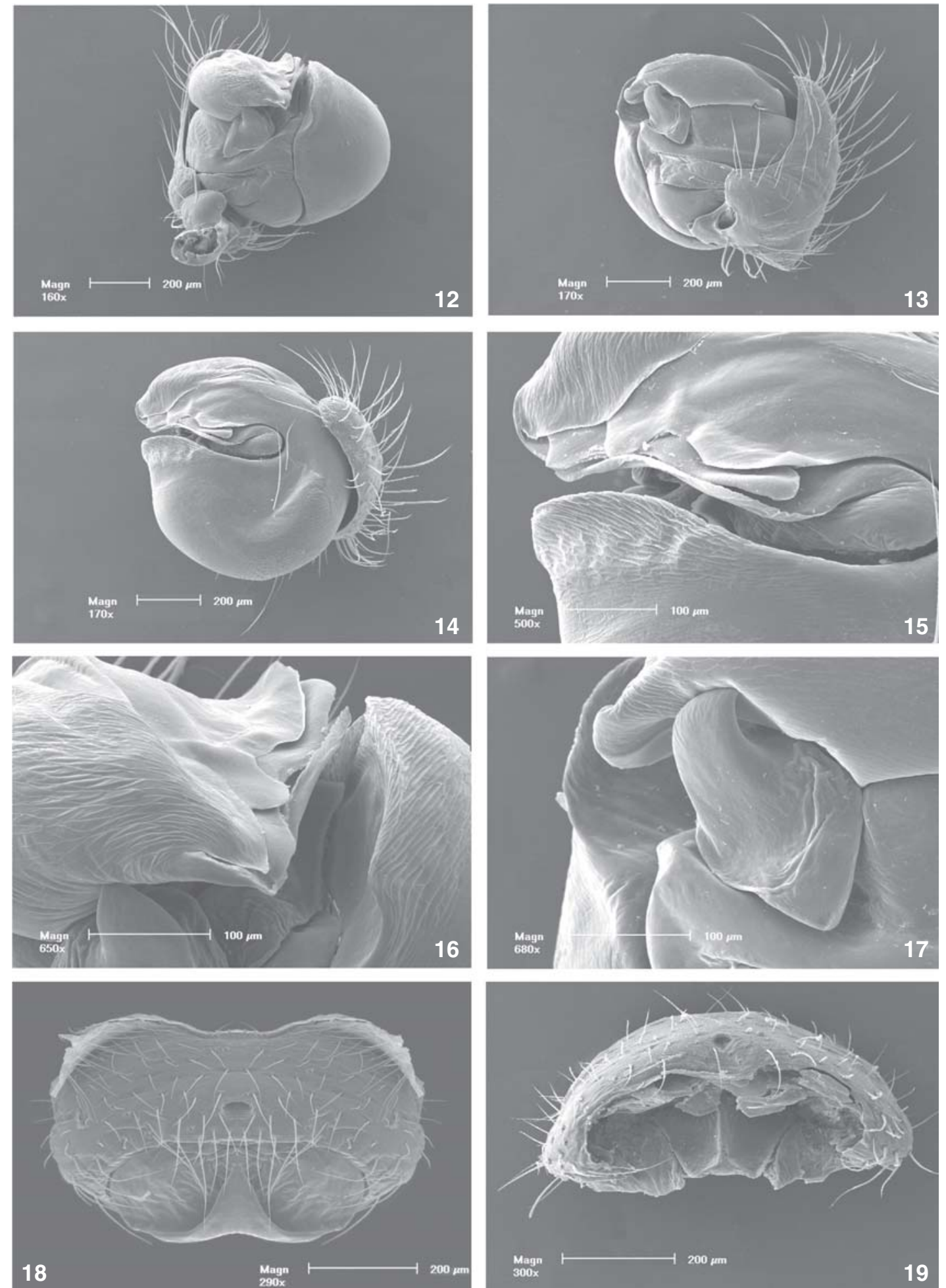

Figures 12-19. Naatlo serrana sp. nov.: (12-17) male palp: (12) ventral view; (13) mesal view; (14) apical view; (15) embolus, detail; (16) embolus and conductor, detail; (17) median apophysis, detail; (18-19) female epygine: (18) ventral view with flap; (19) posterior view, flap removed.

Revista Brasileira de Zoologia 25 (2): 299-308, June, 2008 

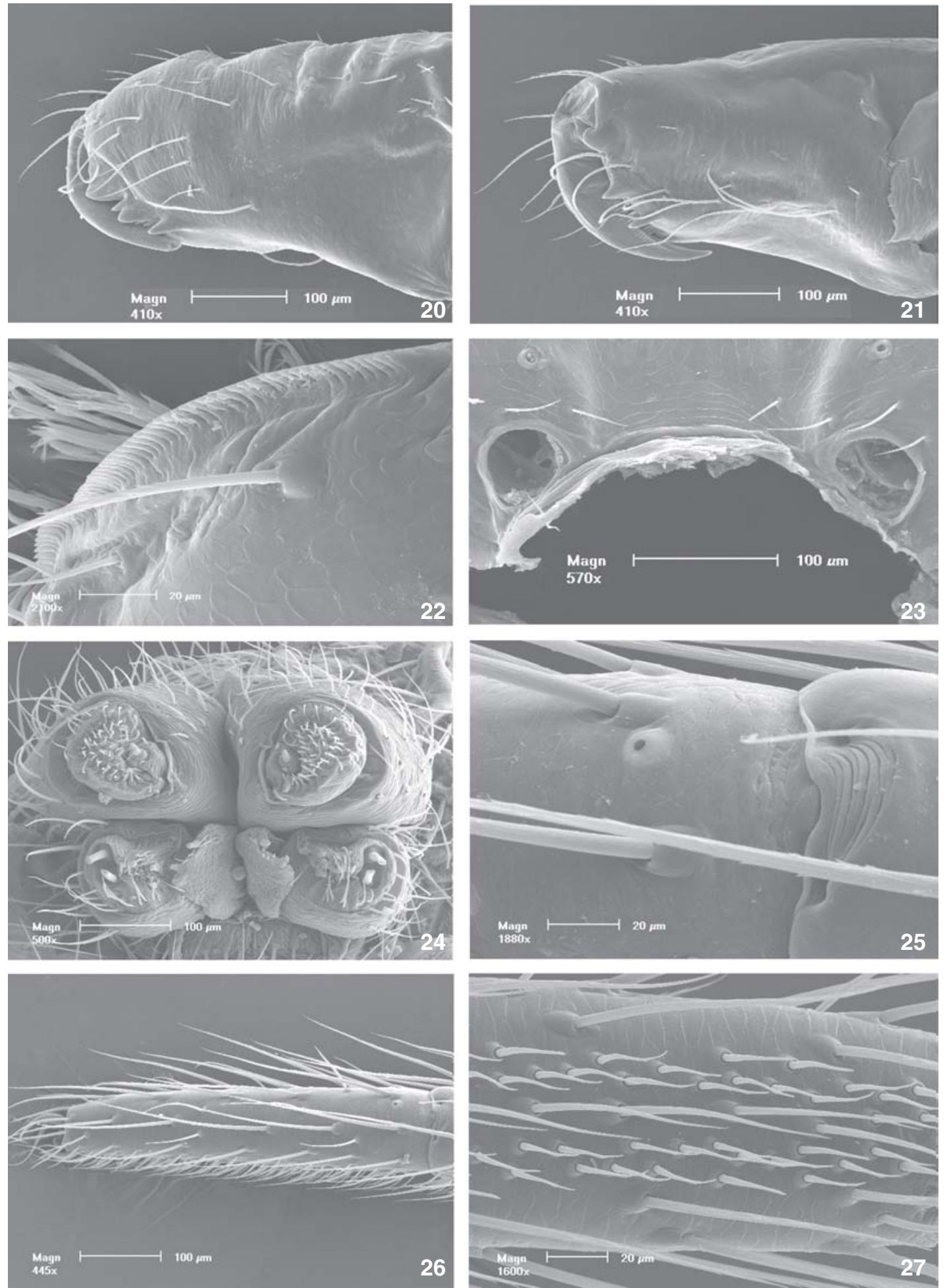

Figures 20-27. Naatlo serrana sp. nov.: (20-24) female: (20) chelicerae, anterior view; (21) chelicerae, posterior view; (22) endite and serrula, detail anterior view; (23) sternum, detail pits; (24) spinnerets, general view; (25-27) male: (25) tarsal organ, leg l; (26) tarsus of leg I; (27) tarsus of leg I, ventral view, detail.

Revista Brasileira de Zoologia 25 (2): 299-308, June, 2008 
Diagnosis. The male palpus of Naatlo serrana sp. nov. (Figs 1-5 and 12-17), is similar to the one of $N$. sutila Coddington, 1986 (Coddington 1986, figs 70-72, 82 and 83) by the well developed conductor, distally acute and by the median apophysis running over the tegulum, but can be distinguished by the shape of the cymbium with a dorsal projection (Figs 2, 3 and 13), median apophysis with a pronounced hook shape apical tip (Figs 1-3 and 17), narrower distal area of embolus with lateral projection less developed (Figs 5 and 15) and lateral margins without teeth. The female is similar to the $N$. sutila Coddington, 1986 (Coddington 1986, figs 78-80), by the presence of the flap on the epigynum (Figs 9 and 18) and absence of internal lateral lobes (Fig. 10), as occur in N. splendida (Taczanowski, 1873) (CodDington 1986, fig. 89) and N. fauna (Simon, 1897) (Coddington 1986, fig. 94), but differs by the posterior margin of the flap that present two median sclerotized excavations, half moon shape, forming a triangular structure extending almost to the posterior base (Figs 9 and 18). According to Coddington (1986: 44, 45), males and females can be distinguished by the color pattern with silvery dots along the abdomen, pattern not verified in the species here in described.

Description. Male holotype. 2.76 total length. Carapace 1.32 long, 1.16 wide, 0.64 height, on the cephalic region. Sternum 0.66 long, 0.54 wide. Clypeus 0.30 height. Abdomen 1.68 long, 1.40 wide, 1.40 height. Legs 1,2,4,3. Measurements I/II/ III/IV: femura 1.24/1.04/0.72/0.84; patellae 0.52/0.48/0.24/0.36; tibiae 1.04/0.88/0.44/0.48; metatarsi 0.92/0.80/0.44/0.48; tarsi 0.48/0.40/0.32/0.36; total 4.20/3.60/2.16/2.52. Carapace (Figs 6 and 8) reddish-chestnut with the sternum and cephalic region paler. Endites and chelicerae (Fig. 7) yellowish-chestnut. Legs (Figs 25-27) articles yellowish-chestnut, except metatarsi and tarsi dark chestnut. Femur I e II stronger than III e IV. Abdomen (Figs 6-8), dorsally yellow with small rounded chestnut dots. Lateral, posterior region and area around spinnerets chestnut. Eyes heterogeneous, AME dark, the other pearly; AME something shorter than the other ones, PME, PLE e ALE, same size. Anterior ocular row 0.46 wide, posterior 0.50. Median ocular quadrangle longer than wide (0.28-0.26). Palpus with median apophysis well sclerotized, tegulum very developed, paracymbium inconspicuous and cymbium with many long hairs (Figs 1-5).

Female. (MCTP 14079). Total length 4.43. Carapace 1.62 long, 1.31 wide, cephalic region 0.68 height. Sternum 0.76 long, 0.64 wide. Clypeus 0.20 height. Abdomen 3.06 long, 2.62 wide, 2.31 height. Legs 1,2,4,3. Measurements I/II/III/IV: femura 1.25/ 1.18/0.68/1.00; patellae 1.18/0.62/0.43/0.43; tibiae 1.00/0.93/ $0.50 / 0.75$; metatarsi $0.81 / 0.75 / 0.56 / 0.75$; tarsi $0.43 / 0.43 / 0.37 /$ 0.37; total 4.67/3.91/2.54/3.30. Carapace and sternum (Fig. 23) reddish chestnut, cephalic region lighter. Pits very developed (Fig. 23). Endites and chelicerae (Figs 20-22) yellowish chestnut. Legs with femura yellowish chestnut, the remaining articles dark-chestnut. Femur I and II more robust than III and
IV. Dorsum of abdomen yellowish with small rounded chestnut dots. Laterals chestnut, venter dark chestnut around spinnerets (Fig. 24). Eyes heterogeneous. AME dark, the remaining pearly. ALE and PME bigger than PLE and AME. Posterior ocular row 0.58, wider than anterior one, 0.52. MOQ 0.38 long, 0.36 wide. Epigynum with the flap wider than long (Figs 9, 18 and 19), copulatory bursae elongate with furrows and spermathecae circular (Fig. 11).

Variation. Total length (10 males) 1.93 to 2.87 ; (10 females) 3.12 to 4.43 .

Other material examined. BraziL, Rio Grande do Sul: São Francisco de Paula, Centro de Estudos e Conservação da Natureza Pró-Mata, 4 males and 34 females, 21-24.III.1995-16-17.II. 2001, all collected by A.A. Lise leg. (MCTP 8313, 9854, 10425, 10809, 11917, 12023, 12024, 12942, 13762, 14077, 14233, 14234, 14354, 14493, 15609, 15610, 15778, 15779), 2 females, 29.IV.2001, A. Braul Jr. leg. (MCTP 13044); same locality and collector, 1 female, 4.V.1974, (MCN 2092); same locality, 2 females, 19-22.III.1998, L.A. Moura leg. (MCN 29181); same locality, 2 females, 5.III.1956, T. de Lema leg. (MCN 1898).

Distribution. Brazil: Rio Grande do Sul (Fig. 55).

\section{Naatlo maturaca sp. nov.} Figs 28-54

Types. Male holotype from Brazil, Amazonas: São Gabriel da Cachoeira, Maturacá, 14.X.1990, A.A. Lise leg. (MCTP 1443). Paratypes: 6 females, same locality and collector as holotype, 12.X.1990, (MCTP 1226, 19541); 1 male and 1 female, Benjamin Constant, XII.1979 (MCN 8914); 1 male and 1 female, Manaus, Reserva Florestal Adolpho Ducke, 18.XIII.1987, all collected by A.A. Lise (MCN 8914, 32593); 1 male and 2 females from BraziL, Pará: Melgaço, Caxiuanã, Estação Científica Ferreira Penna, 11.VIII.1996, A.A. Lise leg. (MCTP 9493).

Etymology. The specific name is a noun in apposition to the type-locality.

Diagnose. The male palpus of Naatlo maturaca sp. nov. (Figs 28-32, 39 and 40), is similar to N.sutila Coddington, 1986 (Coddington 1986, figs 70-72, 8 and 83) and N. serrana sp. nov. (Figs 1-5), but can be distinguished by the shape of cymbium that has a dorsal projection pronounced, distal area of embolus wider and with lateral projection well developed (Figs 32 and 40). The female is also similar to the one of $N$. sutila Coddington, 1986 (CoDDINGTON 1986, figs 78-80) and N. serrana sp. nov. (Figs 9-11), but can be distinguished from N. sutila by the copulatory bursae being more elevated (Fig. 38). Can be distinguished from de N. serrana sp. nov. by the position of the spermathecae on the same transversal plane on the anterior portion. The color pattern described by CoDDINGTON (1986: $44,45)$ for the species described till now, with silvery dots along the abdomen, differ, from N. maturaca sp. nov. and can be separed from $N$. serrana sp. nov. by having ring-shaped dark chestnut spots between tibiae and tarsi of legs, sternum (Fig. 

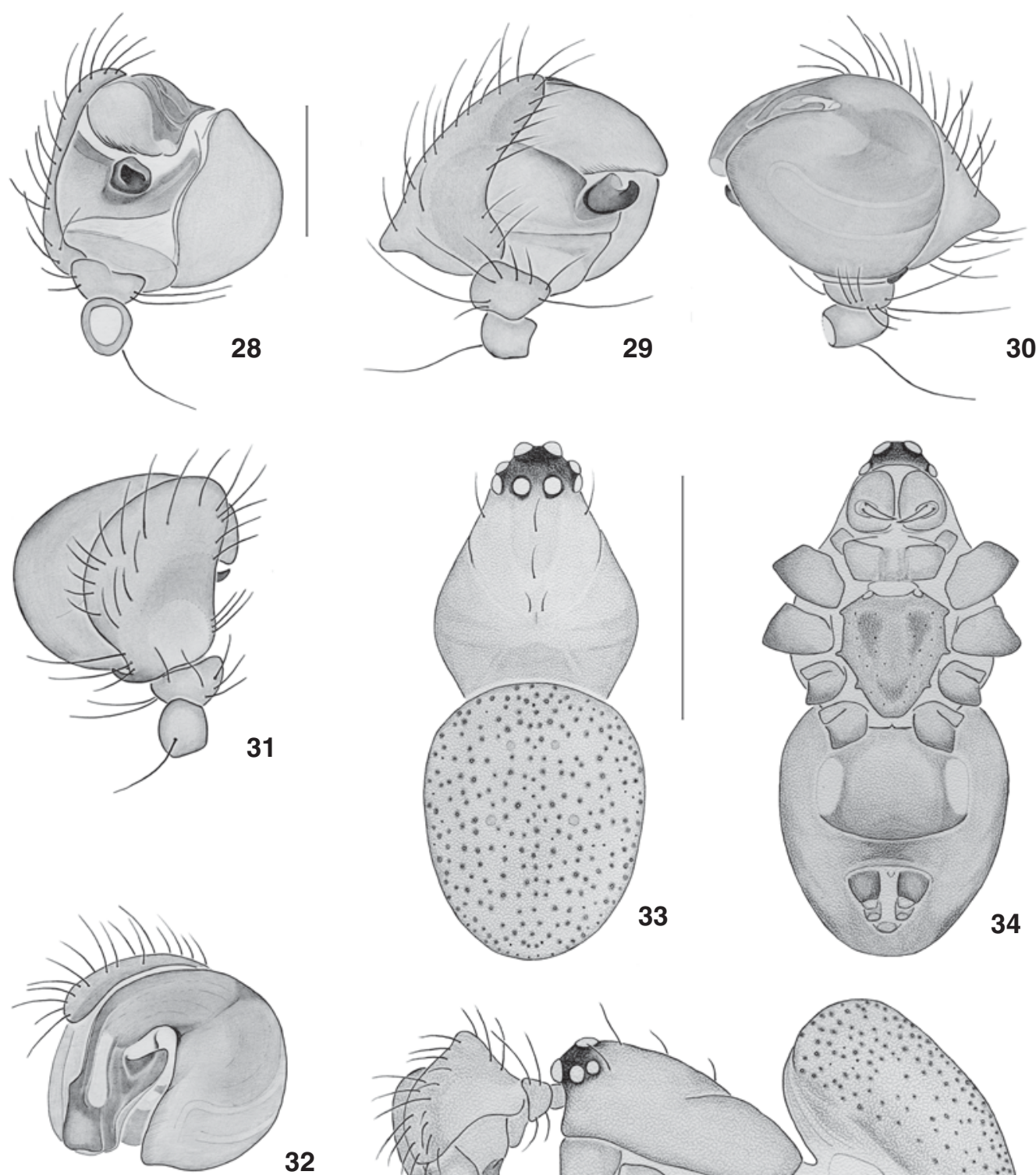

33

32
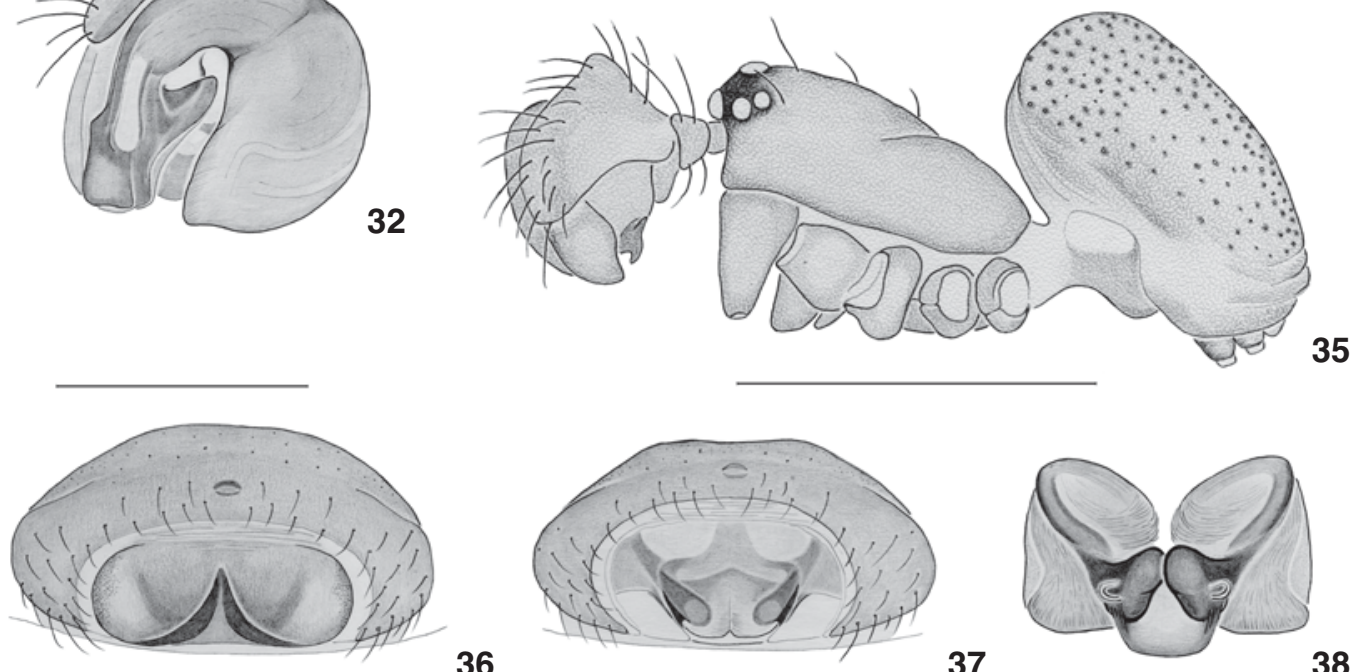

37

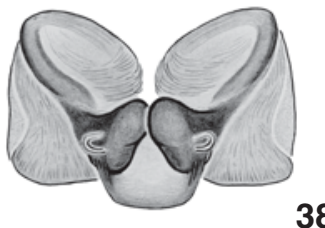

Figures 28-38. Naatlo maturaca sp. nov.: (28-32) male palp: (28) ventral view; (29) ectal view; (30) mesal view; (31) dorsal view; (32) apical view; (33-35) male body: (33) dorsal view; (34) ventral view; (35) lateral view; (36-38) female epygine: (36) ventral view; (37) ventral view, flap removed; (38) dorsal view, cleared. Scale lines: $(28-32,36-38) 0,5 \mathrm{~mm},(33-35) 1 \mathrm{~mm}$.

Revista Brasileira de Zoologia 25 (2): 299-308, June, 2008 

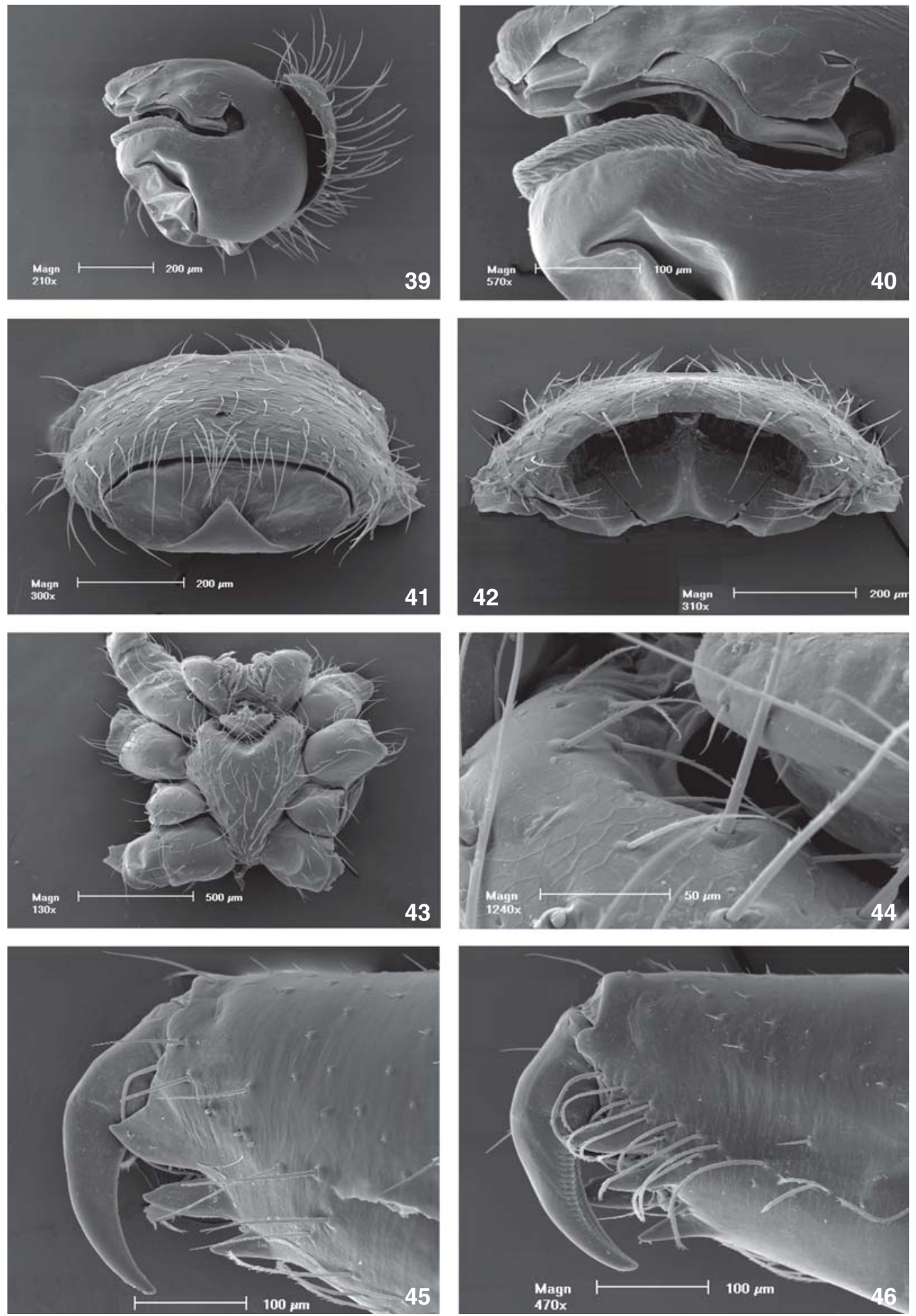

Figures 39-46. Naatlo maturaca sp. nov.: (39-40) male palp: (39) apical view; (24) embolus, detail in apical view; (41-46) female: (41) epygine in ventral view with flap; (42) posterior view, flap removed; (43) cephalotorax, ventral view; (44) labium and sternum, detail pits; (45) chelicerae, anterior view; (46) chelicerae, anterior view.

Revista Brasileira de Zoologia 25 (2): 299-308, June, 2008 

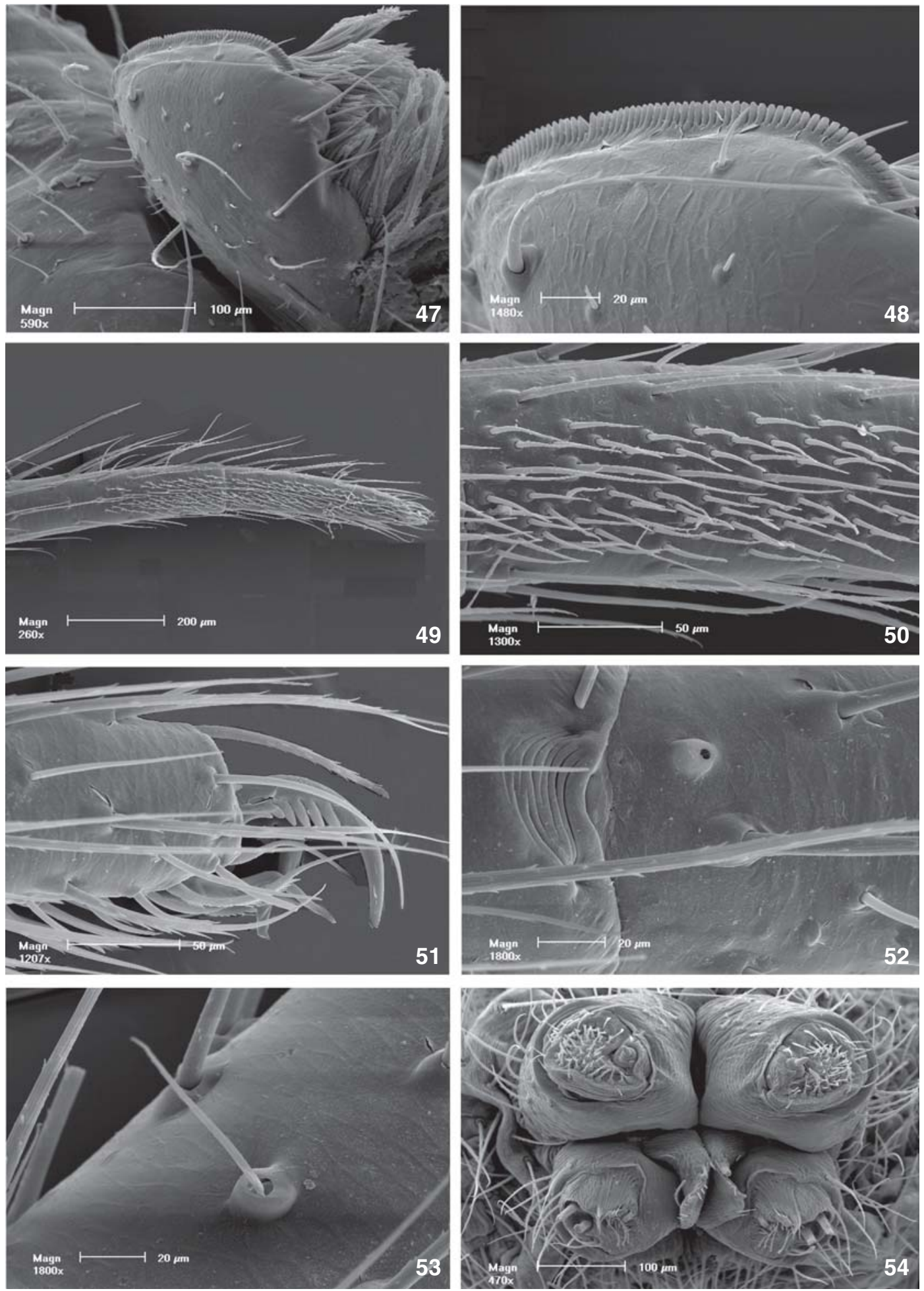

Figures 47-54. Naatlo maturaca sp. nov.: (47-54) female: (47) endite, anterior view; (48) endite and serrula, detail anterior view; (49) metatarsus and tarsus of leg l; (50) tarsus of leg I, ventral view, detail; (51) tarsal claw of leg l; (52) tarsal organ, leg l; (53) dorsal trichobotria of leg I; (54) spinnerets, general view.

Revista Brasileira de Zoologia 25 (2): 299-308, June, 2008 
34) and coxae with chestnut spots and ocular area (Fig. 33) blackish.

Description. Male holotype. Total length 2.03. Carapace 1.09 long, 0.94 wide, cephalic region 0.63 height. Sternum 0.53 long, 046 wide. Clypeus 0.16 height. Abdomen 1.25 long, 0.97 wide, 0.81 height. Legs $1,2,4,3$. Measurements, I/II/III/IV: femura 0.86/0.74/0.50/0.64; patellae 0.38/0.36/0.24/0.28; tibiae $0.76 / 0.58 / 0.40 / 0.52$; metatarsi 0.58/0.50/0.36/0.48; tarsi $0.34 /$ 0.32/0.26/0.26; total 2.92/2.50/1.76/2.18. Carapace (Figs 33 and $35)$ light yellow, ocular area blackish. Chelicerae and endites (Fig. 34) light yellow. Sternum (Fig. 34) light yellow with chestnut spots on the anterior laterals and the posterior region. Coxae and femura light yellow, the former with distal chestnut margins. Femura I and II stronger than III and IV. Patella, tibia, metatarsus and tarsus of legs I and II reddish chestnut. Legs III and IV with circular dark chestnut spots between the articles. Abdomen rounded, dorsally light yellow with small chestnut dots. Laterals with chestnut spots. Venter with a median longitudinal chestnut stripe and so is the region around the spinnerets. Eyes heterogeneous. AME a little bit bigger than the other ones, PME and PLE same size and ALE smaller than the other ones. Posterior ocular row 0.38, anterior 0.36. MOQ 0.24 long, 0.22 wide. Palpus, cymbium with dorsal projection pronounced (Figs 29 and 30), paracymbium rudimentary and tegulum very developed (Figs 28, 30, 31 and 39).

Female (MCTP 19541). Total length 3.64. Carapace 1.44 long, 1.12 wide, cephalic region 0.80 height. Sternum 0.69 long, 0.56 wide. Clypeus 0.16 height. Abdomen 2.32 long, 2.44 wide, 2.16 height. Legs 1,2,4,3. Measurements I/II/III/IV: femura 0.82/ $0.82 / 0.64 / 0.82$; patellae $0.56 / 0.48 / 0.22 / 0.40$; tibiae $0.68 / 0.68 /$ $0.40 / 0.68$; metatarsi $0.64 / 0.60 / 0.44 / 0.64$; tarsi $0.34 / 0.36 / 0.22 /$ 0.36 ; total 3.04/2.94/1.92/2.90. Carapace light yellow with ocular area blackish. Endites (Figs 43, 47 and 49) and chelicerae (Figs 45 and 46) light yellow. Sternum (Figs 43 and 44) light yellow. Sternum light yellow with chestnut spots on the anterior laterals and posterior region. Coxae (Fig. 43) and femura light yellow. Coxae with distal margin chestnut. Femura I and II stronger than III and IV. Legs (Figs 49-53) I and II with patella, tibia, metatarsus and tarsus reddish chestnut. Legs III and IV with dark chestnut ring shape spots on the articles articulations. Abdomen dorsally light yellow with some chestnut small spots. Laterals with chestnut spots. Venter with a median longitudinal chestnut stripe and so is the region around the spinnerets (Fig. 54). PME and AME some bigger than the other ones. ALE and PLE same size and smaller than the other. Anterior ocular row 0.38 wide, posterior 0.36 . MOQ 0.30 long, 0.28 wide. Epigynum with flap wider than long, esclerotized posteriorly (Fig. 36), spermathecae circular, copulatory bursae elongated and striated (Figs 37 and 38).

Variation. Total length (5 males) 1.90 to 2.40; (10 females) 3.24 to 3.76 .

Other material examined. BraziL, Amazonas: Manaus, Reserva Florestal Adolpho Ducke, 2 females, 12.III.1987, A.A. Lise leg. (MCN 32589, 32594); same locality, 1 male, 15-23.VIII.
1991, A.D. Brescovit leg. (MCN 21531); same locality, 1 female, 19.IX.1973, L.P. Albuquerque leg. (MCN 32589); Benjamin Constant, 1 male, XII.1979, A.A. Lise leg. (MCN 8887); Mato Grosso: Chapada dos Guimarães, 2 females, 15-26.VII.1992, A.A. Lise leg. (MCTP 2199); Santo Antônio de Leverger, 2 females, 29.VII.1992, A.A. Lise leg. (МСТP 2390).

Distribution. BraziL: Amazonas, Pará and Mato Grosso (Fig. $55)$.

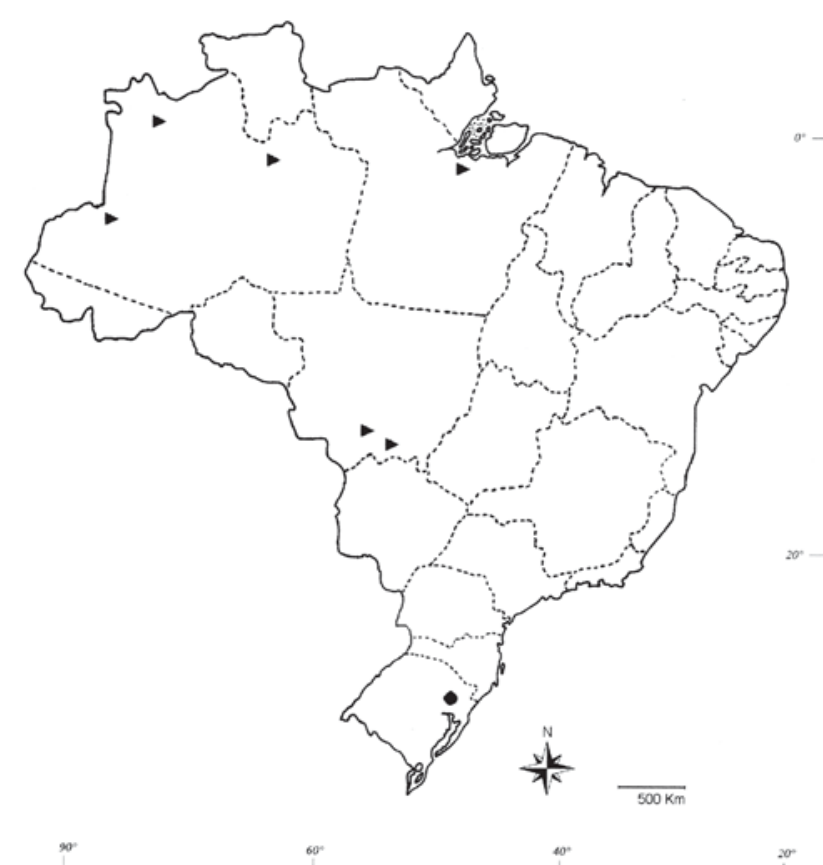

Figure 55. Map of South America, showing the distribution of $N$. serrana sp. nov. (๑) and N. matura sp. nov. ( ) in Brazil.

\section{ACKNOWLEDGEMENTS}

We want to acknowledge Erica H. Buckup (MCN) and Norman I. Platnick (AMNH) by the informations; to the staff of Centro de Miscroscopia e Microanálises of PUCRS, for the help in obtaining the SEM images; the direction of MCN by permitting the first author to develop part of this work in it dependences. This study was supported by CNPq (process 140586/20075 for E.N.L.Rodrigues from Programa de Pós Graduação em Biologia Animal da Universidade Federal do Rio Grande do Sul).

\section{LITERATURE CITED}

Coddington, J.A. 1986. The genera of the spider Family Theridiosomatidae. Smithsonian Contributions to Zoology 422: 1-96.

Coddington, J.A. 1990. Ontogeny and homology in the male palpus of orb-weaving spiders and their relatives, with comments on phylogeny (Araneoclada: Araneoidea, Deinopoidea). Smith- 
sonian Contributions to Zoology 496: 1-52.

Platnick, N.I. 2007. The world spider catalog, version 7.5.

American Museum of Natural History. Available in the World

Wide Web at: http://research.amnh.org/entomology/ spiders/catalog/index.html [Accessed in 16/V/2007]

Rodrigues, E.N.L. \& R. Otт. 2005. Aranhas da família Theridiosomatidae: espécie nova e novas ocorrências no Brasil. Iheringia, Série Zoologia 95 (4): 441-443.

Received in 20.VI.2007; accepted in 17.III.2008.

Editorial responsibility: Georgina Bond-Buckup 